\title{
The Secrets of Indians: Native Knowers in Enlightenment Natural Histories of the Southern Americas
}

\author{
Stefanie Gänger
}

The "primitive inhabitants of Peru," as José Hipólito Unánue (1755-1833) put it in his 1791 essay on the nascent discipline of botany in the Viceroyalty of Peru, had long been "excellent herbalists (excelentes herbolarios)." "Devoted to empirical agriculture and medicine," they had come to discover the virtues of many plants and most of the country's historians were agreed that the Indians' plant knowledge, passed on "from parents to children by the ministry of the word (de padres a hijos por el ministerio de la palabra)," was superior to that even "of the medical profession (médicos de profesión)." For Unánue and his intellectual community of naturalists that knowledge was virtually lost, however. For, in his view, "in the wake of the upheaval of the conquest," the Indians' temper had become "mysterious, stubborn and mistrustful" and led them "to conceal their knowledge from the Europeans." Neither flattery nor bribery nor threats of violence would induce them to betray their secrets and it was only sometimes, through the imprudence or treason of one of them, that their knowledge about the virtues of medicinal plants was ever unveiled to outsiders. ${ }^{1}$

The topos of the reluctant Indian informer, unwilling to share his or her excellent, empirical knowledge of botany, medicine, agronomy, and other areas of natural historical inquiry, was one of the earliest and most enduring elements of conventional wisdom about the inhabitants of the New World - an obsession "fixed in a pattern," as the art historian Natalia Majluf put it, traceable to the very beginning of the colonial period, and "repeated and recreated obsessively" thereafter. ${ }^{2}$ Although countless studies have in recent years examined

1 José Hipólito Unanue, "Botánica. Introducción a la descripción científica de las plantas del Perú, vol. II, núms. 43 y 44, 68-86," in ElMercurio Peruano:179o-1795. Antología, ed.Jean-Pierre Clément (Frankfurt am Main: Vervuert, 1998 (1791)), 96-97.

2 In the context of her study on the theme of the Indian in modern Peruvian painting, Natalia Majluf examined representations of "the widespread stereotype" "of the silent Indian" "who refuses to communicate with the Creole." She argues that it "can be traced back to the colonial period" but "gained new relevance within the late 18th century interest in archaeology 
one or another aspect of native "skill in nature" in and beyond Spanish and Portuguese America and the Caribbean - its stereotypical nature, ${ }^{3}$ profitable commodification, ${ }^{4}$ or prejudiced erasure and dismissal ${ }^{5}$ - the roots and history of the "inscrutable" native knower as an epistemic category has yet to be the focus of historians' attention. This contribution is concerned with the intellectual ancestry and genealogy of the topos of the secretive Indian knower of New World territories and nature, which flourished in enlightened natural histories and travelogues concerned with the Southern Americas. It argues that the widespread and long-lived trope of the "mistrustful" native knower was, like other archetypes of indigeneity - the "man-eating" Indian, ${ }^{6}$ the non-acquisitive, "idle" Indian, who needed to be coerced into labour, ${ }^{7}$ or "the ecological Indian," living "in harmony," and sustainably, with his natural environment ${ }^{8}$ - a historicizeable cultural discourse with identifiable roots in Christian and humanist legacies. In a first part, the paper sketches the contours of the topos; in a second part it traces its resemblance to, and intellectual kinship with, other inscrutable, "illiterate knowers" in late-medieval and early

and the description of the country's geography." Natalia Majluf, The "Creation of the Image of the Indian in 19th-Century Peru: The Paintings of Francisco Laso (1823-1869)" (PhD diss., University of Texas, 1996), 350-51.

3 On the attribution of 'skill in nature' to the "ecological Indian," see Shepard Krech, The Ecological Indian: Myth and History (New York: W. W. Norton, 1999), 19. Exotic man's "impenetrable inscrutability" is generally acknowledged to be an enlightened stereotype. George S. Rousseau and Roy Porter, "Introduction: Approaching Enlightenment Exoticism," in Exoticism in the Enlightenment, ed. George S. Rousseau and Roy Porter (Manchester, New York: Manchester University Press, 199o), 4-5. Natalia Majluf first pointed to the stereotypical nature of the "inscrutable Indian" in Andean South America. Majluf, "The Creation of the Image of the Indian in 19th-Century Peru." For North America, see Susan Scott Parrish, American Curiosity: Cultures of Natural History in the Colonial British Atlantic World (Chapel Hill: University of North Carolina Press, 2006), 217.

4 On the history of colonial "bioprospecting," see Londa Schiebinger, Plants and Empire (Cambridge, MA, London: Harvard University Press, 2004); Schiebinger, "Prospecting for Drugs. European Naturalists in the West Indies," in The Postcolonial Science and Technology Studies Reader, ed. Sandra Harding (Durham, London: Duke University Press, 2011).

5 See, for instance, Kathleen S. Murphy, "Translating the Vernacular: Indigenous and African Knowledge in the Eighteenth-Century British Atlantic," Atlantic Studies 8, no. 1 (2011).

6 The cannibal epithet has been applied to different human groups over the centuries - more prominently, America's Aztec and Tupinambá societies in the wake of the Iberian conquest. See, for instance, the classic work by William Arens, The Man-Eating Myth:Anthropology and Anthropophagy (Oxford: Oxford University Press, 1979), 10-13.

7 "Idleness," long attributed in humanist thought to the "poor" and to beggars, was transferred to an entire society - the Indians - in the wake of the conquest. See Nicolas Sanchez-Albornoz, "El trabajo indigena en los Andes: Teorías del siglo XVI," Revista ecuatoriana de historia económica 2 (1987): 173.

8 Krech, The Ecological Indian: Myth and History. 
modern Europe - "rustics" and peasants, "simpletons," and women -; in a last part, it studies the grounds of the stereotype's worldwide propagation and dissemination during the Enlightenment. Though the essay traces the association between indigeneity, secrecy, and skill in nature across the Americas and into our present, its analytical focus rests on the liminal space of post-conquest Spanish America. As shall be shown, it was in this first period of "upheaval," decades before Portugal, England, and France came to the exploration of New World nature, ${ }^{9}$ that early modern observers first sought to make sense of, and classify, the knowledge of America's new-found inhabitants, to suit their epistemic paragons and to make it familiar. ${ }^{10}$

\section{Unalienable Truths}

The figure of the Indian informer, anxious to "conceal" his or her "excellent," "empirical" knowledge of the land, was an iconic form in natural historical writings concerned with the Southern Americas in the late 1700 and early 180os-a field of enquiry that, in the Iberian tradition at least, encompassed the collecting and study of mined silver, medicinal bezoars, "curious" antiquities, and valuable timber alike in the period. ${ }^{11}$ The trope was prevalent in creole writings and some of the earliest foreign travelogues, which contained various anecdotes about how "the Indians," out of "hatred," had concealed from officials the "situation of a mine,"12 or the site of "ancient monuments" dating back to the time before the arrival of the Spanish. ${ }^{13}$ It flourished particularly, however, in natural historical writings devoted to the healing and poisonous properties

9 Scott Parrish, American Curiosity, 28.

10 For a discussion of the vast literature on this matter, see Karen Ordahl Kupperman, "Introduction: The Changing Definition of America," in America in European Consciousness, 1493-1750, ed. Karen Ordahl Kupperman (Chapel Hill, London: University of North Carolina Press, 1995). "News out of the newfound world" is a reference to the English translation of Monardes's history: Nicolás Monardes, Joyfull Newes out of the Newe Founde Worlde (London: Willyam Norton, 1577).

11 Paula De Vos, "The Rare, the Singular, and the Extraordinary: Natural History and the Collection of Curiosities in the Spanish Empire," in Science in the Spanish and Portuguese Empires, 1500-1800, ed. Daniela Bleichmar, Paula de Vos, Kristin Huffine, and Kevin Sheehan (Stanford: Stanford University Press, 2009).

12 Johann Jakob von Tschudi, Peru: Reiseskizzen aus den Jahren 1838-1842, 2 vols., vol. 2 (St. Gallen: Scheitlin und Zollikofer, 1846), 138-139.

13 D.F.D.P.D.L.M.L., "Carta remitida a la Sociedad, que publica con algunas notas," Mercurio Peruano, no. 344 (1794): 257. Also cited in Majluf, "The Creation of the Image of the Indian in 19th-Century Peru," 351. 
of plants. From the Spanish and Portuguese American Viceroyalties of Peru, New Spain and Brazil to the colonial Caribbean, countless writers eulogized the "marvellous cures" of "wild Indians", who possessed greater "skill in simples, and the virtue of plants," "than the whites," but who "guarded their secrets" and could almost never be "persuaded" - that is, flattered, bribed, or coerced - to instruct naturalists "coming from Europe."14 Enlightened Jesuit chroniclers, ${ }^{15}$ French expeditionaries ${ }^{16}$ and Mexican physicians ${ }^{17}$ alike were all familiar with one or another anecdote about how the "secrets" of antidotes to arrow poison, of the "salutary virtue" of cinchona - a febrifuge - or of the healing properties of lizard meat, had been extorted from "the Indians" by way of deceit, furtive observation, or "the arts of intimacy." As Alexander von Humboldt (1769-1859), a paragon for later travellers in many respects, put it following his stay with a "master of curare (amo del curare)" in the upper Orinoco valley, "a veil of secrecy" lay everywhere over the "wild Indians" (Wilden) knowledge of "poisons and antidotes." 18 "The Indians" only rarely "betrayed" of their own volition the "secrets" they had, by all accounts, "sworn to keep among themselves, because of their hatred of their enemies." ${ }^{19}$ Those who did were mostly "wom[e]n" who,

14 Eighteenth-century Brazilian surgeons like Luís Gomes Ferreira (1686-1764), for instance, confided in the plant knowledge and experience of the inhabitants of the Sertão, in particular the Carijós. Júnia Ferreira Furtado, ed. Luís Gomes Ferreira, Erário mineral (Rio de Janeiro: Editora fiocruz, 2002 [1735]), 28-29. For examples from the Caribbean, see Schiebinger, "Prospecting for Drugs," $113-20$.

15 Friar José Guevara (1719-1806) suspected that the Spanish, desirous to learn the antidote, injured an Indian prisoner with a poisoned arrow and freed him so he would look for the medicinal plant and thus betray his knowledge. José Guevara, Historia de la conquista del Paraguay, Rio de la Plata y Tucuman (Buenos Aires: E. Ostwald, 1882 [around 1766]), 208.

16 Charles-Marie de la Condamine, "Sur l'arbre du quinquina," Mémoires de l'Academie Royale MDCCXL (1738 (1737)): 233-34.

17 On the "secret uses" of lizard meat, see José Vicente Garcia de la Vega, Discurso critico que sobre el uso de las lagartijas, como especifico contra muchas enfermedades, produjo D. Joseph Vicente García de la Vega, Profesor de Medicina en la Imperial Corte de Mexico (Mexico: Imprenta de D. Felipe de Zúñiga y Ontiveros, 1782), 18. Cited in Miruna Achim, "Los remedios de los indios 'nuevamente descubiertos," in Lagartijas medicinales: Remedios americanos y debates científicos en la Ilustración, ed. Miruna Achim (Mexico: Conaculta/UAM-C, 2008), 75 .

18 Alexander von Humboldt, Reise in die Äquinoktial-Gegenden des Neuen Kontinents, 2 vols., vol. 2 (Frankfurt am Main, Leipzig: Insel-Verlag, 1991 [1814]), 1190.

19 François Citte, "De l'usage du quinquina et des règles de son application dans les fièvres intermittentes," in Collection des thèses soutenues a l'école de médicine de Montpellier pendant l'an XII, ed. L'École de Médicine de Montpellier (Montpellier: G. Izar et A. Richard, 1804), 4. For a similar remark see Francisco José de Caldas, Memoria sobre el estado de las quinas en general y en particular sobra la de Loja, Anales de la Universidad Central de Quito (Quito: Tipografía y Encuadernación Saletiana, 1907 [1809]), 242. 
"enamoured with a Spaniard, and afraid to see [their] lover dying," "revealed to him (lui découvrit) the means of finding relief."20 The theme of the Peruvian woman betraying her medical knowledge on account of love, friendship, or compassion even found its way into the realm of literature and the theatre. In Félicité de Genlis' (1746-1830) 1818 novel "Zuma, or the Discovery of Cinchona" (Zuma, ou la découverte du quinquina), which was later adapted for the stage and the opera in England, France, and the Netherlands, Zuma, "the most beautiful of Indian women" and the faithful protégé of a dying Spanish Countess, revealed the secret of the medicinal properties of cinchona to save her benefactress' life. ${ }^{21}$

The trope of the mistrustful Indian knower of nature certainly predated the late 1700 and early 1800 s, the decades in which Unánue authored his essay on the discipline of botany in Peru. "Indians" who knew "many herbs to cure" illnesses but continuously put off "curious gentlemen" who sought to learn their secrets - even though they threatened the Indians, exerted violence, or promised them "such good pay, with flattery and kindness" - had already made their appearance in various prominent seventeenth-century naturalist treatises, such as the Dutch physician Willem Piso's (1611-1678) 1648 Historia naturalis Brasiliae (Natural History of Brazil), ${ }^{22}$ the Jesuit friar Bernabé Cobo's (1580-1657) 1653 Historia del Nuevo Mundo (History of the New World),, 23 and Sebastianus Badus's 1663 Anastasis Corticis Peruviae (Redemption of

20 Citte, "De l'usage du quinquina et des règles de son application dans les fièvres intermittentes," 4. For an example of a male traitor, see George Motherby, A New Medical Dictionary (London: J. Johnson, 1775), Entry CORTEX PERUVIANUS.

21 Stéphanie Félicité du Crest de Saint-Aubin, Countess de Genlis, Zuma, ou la découverte du quinquina (Paris: Maradan, Libraire, 1818), 10-11; 21. For examples of theatrical and operatic adaptations, see, for instance, the comic opera "Zuma, or the Tree of Health," first performed in 1818 in London, Covent Garden. Margaret Ross Griffel, "ZUMA, or, the Tree of Health," in Operas in English: A Dictionary, ed. Margaret Ross Griffel (Plymouth: Scarecrow Press, 2013), 556. For a Dutch adaptation, see Jan de Quack, Zuma, of De ontdekking van den kina-bast: tooneelspel in vier bedrijven (Amsterdam: J. C. van Kesteren, 1819).

22 On Willem Piso's difficulties in acquiring information on poisonous plants from the natives in Dutch Brazil, see Júnia Ferreira Furtado, "Tropical Empiricism: Making Medical Knowledge in Colonial Brazil," in Science and Empire in the Atlantic World, ed. James Delbourgo and Nicholas Dew (New York: Routledge, 2008), 136.

23 Bernabé Cobo, certain that the Indians knew "many herbs to cure" their illnesses, had heard from his correspondents about instances of secrecy in which curious gentlemen had "promised the Indian[s] such good pay, with flattery and kindness" to learn their medical secrets but were put off by them. Bernabé Cobo, Inca Religion and Customs, ed. John Howland Rowe, trans. Roland Hamilton (Austin: University of Texas Press, 1990 (1653)), 222. 
the Peruvian Bark). ${ }^{24}$ Scholars, novelists and playwrights from Britain, the Netherlands, or France - countries where the "black legend" popularized the myth of Spain's unique brutality in the conquest of the New World ${ }^{25}$ were particularly eloquent on instances of Spanish coercion, threat, and violence. Hans Sloane (166o-1753), for instance, in his 1707 Voyage to the Islands Madera, Barbadoes, Nieves, St Christophers, and Jamaica related how "the Indians about Guiana had first discovered [the] Vertue [of Contra Yerva] to the Spaniards," when these threatened an Indian prisoner "to wound him with one of their own venemous [sic] Arrows, if immediately he did not declare their Cure for that Disease, upon which the Indian immediately chaw'd some of this contra yerva, and put it into the wound, and it healed."26

By all appearances, the skilful yet secretive Indian knower of nature had held his own in the New World right from the arrival of the first Spanish and Portuguese conquerors. Already the earliest natural history of the New World, Gonzalo Fernández de Oviedo y Valdés's (1478-1557) 1535 Historia generaly natural de las Indias (General, and Natural History of the Indies) made reference to how "the Indians' were "covetous (avara)" about their knowledge of medicinal "herbs and plants," and "the secrets of nature," "especially about whatever could be useful to the Christians," because "that way this science is [...] their dominion (su señorío)."27 The evidence Unánue cited for his assertion that the Indians concealed their knowledge from the Europeans dated likewise from the sixteenth century. Unánue referred to a 1568 letter from a Lima-based soldier - Pedro de Osma - transcribed in part two of the 1574 "Medicinal History" of the New World (Primera y Segunda y Tercera Partes de la Historia Medicinal

24 Sebastianus Badus' treatise contained the tale of how "the natives" were believed to have hidden their knowledge of the medicinal virtues of the Peruvian bark from the Spanish', and kept it a secret, for a long time. Sebastianus Badus, Anastasis corticis Peruviae; seu chinae chinae defensio (Genoa: Typis Petri Joannis Calenzani, 1663), 21-24.

25 Walter D. Mignolo, Margaret R. Greer, and Maureen Quilligan, "Introduction," in Rereading the Black Legend: Discourses of Religious and Racial Difference in the Renaissance Empires, ed. Walter D. Mignolo, Margaret R. Greer, and Maureen Quilligan (Chicago, London: The University of Chicago Press, 2007).

26 Hans Sloane, A voyage to the islands Madera, Barbados, Nieves, S. Christophers and Jamaica, with the Natural History of the Herbs and Trees, Four-footed Beasts, Fishes, Birds, Insects, Reptiles, \&c. of the last of those islands, 2 vols., vol. 1 (London: B. M., 1707), LV. See also Schiebinger, "Prospecting for Drugs."

27 Gonzalo Fernández de Oviedo y Valdés, Primera parte de la historia natural y general de las indias, yslas e tierra firme del mar oceano (Sevilla: Iuam Cromberger, 1535), book XI, chapter V. On the original manuscript's way into print, see Henry Lowood, "The New World and the European Catalog of Nature," in America in European Consciousness, 1493-1750, ed. Karen Ordahl Kupperman (Chapel Hill, London: University of North Carolina Press, 1995), 308-09. 
de las Cosas que se traen de nuestras Indias Occidentales que sirven en Medicina) authored by Nicolás Monardes (1493-1588), a Seville physician and trader who had never crossed the Atlantic. ${ }^{28}$ De Osma, supposedly a reader of the first part of Monardes' medicinal history who had followed the physician's exhortation to investigate native medicinal knowledge in the New World, allegedly encountered much reluctance among the Indians to divulge their "admirable" understanding of the virtues of medicinal plants and animal substances. When he was seeking to "discover the part in which the bezoar stone is engendered in the vicuñas," de Osma lamented that he could obtain no intelligence from the Indians, "because they are bitter towards us and do not want us to know their secrets." It was an Indian boy, "ten or twelve years of age," who "revealed to" de Osma and his companions the method to extract the bezoar stones and "that instant, his countrymen threatened to slay him."29 "Regardless of kind words and gifts, and of fierce words and threats," de Osma wrote, the Indians, "being wicked and our enemies, will not disclose one secret, or one virtue of a herb, even if they were to see us dying." Other than from children, de Osma told Monardes in the 1568 letter, the conquerors only learned about the medicinal virtues of America's plants from those "Indian women, who get involved with the Spaniards and reveal and tell them everything they know."30

\section{$2 \quad$ Ancestors and Kins[wo]men}

The veracity and accuracy of Fernández de Oviedo y Valdés's account is doubtful and so is that of de Osma's, or rather Monardes's, assertions. As a matter of fact, historians of Iberian science have cited the 1568 letter with some reserve, since there is no evidence to prove it was genuine: de Osma may well have been a creature of Monardes's imagination. ${ }^{31}$ The early and ready acceptance

28 The letter was transcribed in part II of Nicolás Monardes's "Medicinal History (Historia Medicinal)." See Nicolás Monardes, Primera y segunda y tercera partes de la historia medicinal, de las cosas que se traen de nuestras Indias Occidentales, que siruen en Medicina (Sevilla: Alonso Escriuano, 1574), 73-77. For biographical notes on Monardes, see Marcy Norton, Sacred Gifts, Profane Pleasures: A History of Tobacco and Chocolate in the Atlantic World (Ithaca, London: Cornell University Press, 2008), 107-12.

29 Monardes, Primera y segunda y tercera partes de la historia medicinal, 74.

30 Ibid., 77 .

31 Historians of Iberian science have cited de Osma's letter with some reserve. See, for instance, Daniela Bleichmar's remark on "the letter's laudatory tone and the way it dramatizes the importance and utility" of Monardes's work. Daniela Bleichmar, "Books, Bodies, and Fields: Sixteenth-Century Transatlantic Encounters with New World Materia Medica," in Colonial Botany. Science, Commerce, and Politics in the Early Modern World, 
of the idea that the Indians possessed and concealed an "admirable" knowledge of the nature of the New World would appear inconsistent, given its foundation on rather unstable ground, were it not for the possibility that in this, as in so many other instances, familiar, ancient Old World paragons exercised a strong hold over early modern observers' minds and their representations of the New World. ${ }^{32}$ Indeed, the resemblance between the reticent Indian informer and other "illiterate knowers" in late-medieval and early modern thought is conspicuous, and likely eloquent. From the earliest days of colonial rule in the Americas, the Indians "from the fields" - not any Indian, for the category encompassed, into the early nineteenth century, Hispanized, noble or urban persons ${ }^{33}$ - had been likened to Europe's peasantry. Both were "natural men," society-less, poor, uncultured creatures "close in condition, if not in kind, to the animals among which they worked." ${ }^{34}$ A university-trained physician versed in scholastic medicine like Monardes, or a Romance humanist like Fernández de Oviedo y Valdés, would have been familiar with the notion

ed. Londa Schiebinger and Claudia Swan (Philadelphia: University of Pennsylvania Press, 2005), 92. Other historians have, however, stressed the relevance of Monardes's epistolary networks, in ways that suggest the letter may well have been real. Norton, Sacred Gifts, Profane Pleasures, 117. On elements of imaginativeness in Fernández de Oviedo y Valdés's chronicle, see, for instance, Carlo Klauth, Geschichtskonstruktion bei der Eroberung Mexikos: Am Beispiel der Chronisten Bernal Diáz del Castillo, Bartolomé de las Casas und Gonzalo Fernández de Oviedo (Hildesheim: Georg Olms Verlag, 2012), 184.

On the method of "working from affinities with recognizable," Old World "forms" in natural history, see Lowood, "The New World and the European Catalog of Nature," 298. See also Roland Greene, "Petrarchism among the Discourses of Imperialism," in America in European Consciousness, 1493-1750, ed. Karen Ordahl Kupperman (Chapel Hill: University of North Carolina Press, 1995), 135. On the same predicament, see Anthony Grafton, New Worlds, Ancient Texts. The Power of Tradition and the Shock of Discovery (Cambridge, MA: Harvard University Press, 1992), 6; Anthony Pagden, The Fall of Natural Man:The American Indian and the Origins of Comparative Ethnology (Cambridge, New York: Cambridge University Press, 1982), 1-6, 11-12.

33 On elite, or noble, Indians in South and Mesoamerica, see David Cahill, "Colour by Numbers: Racial and Ethnic Categories in the Viceroyalty of Peru, 1532-1824," Journal of Latin American Studies 26, no. 2 (1994); Scarlett O'Phelan Godoy, Kurakas sin sucesiones. Del cacique al alcalde de indios. Perú y Bolivia 1750-1835 (Cuzco: Свс, 1997). In the viceroyalties of Peru and New Spain alike, herbalists usually were described as "simple folks" - men and women who lived "far-off," away from the city, in "Indian villages." See, for instance, Miruna Achim, "From Rustics to Savants: Indigenous Materia medica in Eighteenth-Century Mexico," Studies in History and Philosophy of Biological and Biomedical Sciences 42 (2011): 282.

34 The meaning of "natural man" changed over the centuries, from that of a society-less creature, "something less than human," in the sixteenth and seventeenth centuries, to Enlightenment's "natural man," someone whose mind is unfettered by the moral and intellectual constraints of civil society. Pagden, The Fall of Natural Man, 8-9; 97-98; 21-22. 
that many useful remedies and practices could be learned from "ordinary" laypersons - "rustics" and peasants, "simpletons," or women - whose knowledge was, unlike that of learned scholars, who inquired into "causes or first principles" in the physical operation of natural substances, based on the "accurate but un-theorized observation of phenomena accessible to the senses." ${ }^{35}$ Indeed, accounts of Indian poverty, illiteracy, and simplicity - an image fashioned particularly by the Franciscan order ${ }^{36}$ - would have resonated with early modern thought which, in its reliance on the truths spoken by "illiterate knowers," drew on a genre of Christian piety that placed the best hope of salvation for mankind in the poor and ordinary people, who were closer not only to nature but also to God than the mighty. ${ }^{37}$ From the earliest days of Christianity, the "divine fool" - simple, illiterate, and humble - had told truths and offered hope of redemption. ${ }^{38}$ Writers like Monardes and Fernández de Oviedo y Valdés would have been aware, too, that many "illiterate knowers" - women in particular - communicated their knowledge only to their close associates to other women - orally and in the vernacular, and that they would conceal it from men, since it represented one important way of exerting power over them. They, as well as their readership, would have known also that one of the most important tasks of literate physicians and naturalists consisted of retrieving the "secrets" of women and other artisanal practitioners and committing them to Latin script to ensure their permanence and relative publicity within

35 Katherine Park, Secrets of Women: Gender, Generation, and the Origins of Human Dissection (New York: Zone Books, 2006), 84-85. On how sixteenth-century physicians took seriously what they learnt from laypersons - empirics', artisans, or women -, see Michael Stolberg, "Learning from the Common Folks. Academic Physicians and Medical Lay Culture in the Sixteenth Century," Social History of Medicine 27, no. 4 (2014). On the "mechanic classes" as bearers of valuable empirical knowledge in the seventeenth century, which, however, needed to be "drawn out, freely and disinterestedly reflected upon, and codified for its value to be realized," see also Steven Shapin, A Social History of Truth: Civility and Science in Seventeenth-Century England (Chicago, London: The University of Chicago Press, 1994), 396.

$3^{6}$ Julia McClure, The Franciscan Invention of the New World (Basingstoke: Palgrave, 2016), 178.

37 Harold J. Cook, Matters of Exchange: Commerce, Medicine and Science in the Age of Empire (Hyderabad: Orient Longman, 2008), 34. See also Laurence Brockliss and Colin Jones, The Medical World of Early Modern France (Oxford: Clarendon Press, 1997), 276.

38 The discursive tradition of "divine idiocy," of "holy folly," grew out of the crossings of numerous traditions - early Christian thought, the Enlightenment, and Romanticism, among others. Dana Heller, "Holy Fools, Secular Saints, and Illiterate Saviors in American Literature and Popular Culture," CLCWeb: Comparative Literature and Culture 5, no. 3 (2003): 4,7 . 
an elite scientific community. ${ }^{39}$ And while there may have been a grain of truth in assertions about the Indians' skill in nature and secrecy - during the early years of the Spanish conquest, secrecy was a conduct it would have been perfectly prudent to adopt $\mathrm{t}^{40}$ - they were likely something other, if not rather, than an observation. The stereotype of the "inscrutable Indian knower" may well have been the continuance and transfer of a European topos of long standing to the Americas: one of a plethora of Christian and humanist legacies that the Old World bequeathed to the New. Monardes's Medicinal History was translated into Latin by Carolus Clusius (1526-16o9) in $15^{82}$ and soon after became available in French, German, Italian and English translations, which were reedited several times during the sixteenth and seventeenth centuries. As historians of Iberian medicine have often noted, it was through Monardes that many of early modern Europe's physicians, apothecaries and naturalists were first introduced to the natural world of the Americas. ${ }^{41}$ And, it was probably along this same vein, among others, that the "secretive Indian," the reluctant informer about the New World, put down roots in natural historical discourse.

The image of the reticent Indian informer hibernated in natural histories of the seventeenth century, but re-emerged with new vigour in the Enlightenment when it was reprised by writers like Unánue. In fact, the latter was most likely looking, once more, to the European tradition of 'inscrutable rustics' Monardes had tapped into back in the sixteenth century, when he was trying to come to terms with and classify the knowledge of America's new-found inhabitants. Historians have sometimes noted the striking similarity between colonial encounters in the West Indies and those described by enlightened European naturalists with "wise women," "rustics," or the peasantry.42 And indeed, many enlightened writers from Sweden, England or Prussia alike - Carl Linnaeus (1707-1778) among them - were "keen ethnobotanist[s]," as Lisbet Koerner put it, who studied "the plant lore" and "therapeutic secrets" of "simple folks," "anxious to protect their skills," in ways very much akin to those

39 Parks, Secrets of Women, 84.

40 See, for instance, Suzanne Austin Alchon's reflections on how Indian healing would often actually have occurred in secrecy because of its association with idolatry and consequent repression. Suzanne Austin Alchon, "Tradiciones médicas nativas y resistencia en el Ecuador," in Saberes andinos: Ciencia y tecnología en Bolivia, Ecuador y Perú, ed. Marcos Cueto (Lima: IEP, 1995), 27; 36. On the role of the inquisition, see Achim, "Los remedios de los indios 'nuevamente descubiertos,", 85 .

41 Achim, "From Rustics to Savants," 278.

42 Schiebinger, "Prospecting for Drugs," 121. See also Daniel Rood, "Toward a Global Labor History of Science," in Global Scientific Practice in an Age of Revolutions, 1750-1850, ed. Patrick Manning and Daniel Rood (Pittsburgh: University of Pittsburgh Press, 2016), 265. 
of their contemporaries in Latin America. ${ }^{43}$ The "empirical," "mysterious" Indians' likeness to reticent Swedish peasants was likely anything but accidental. Not only were Spanish and Portuguese American scholars under the influence of European writings - Unánue, for instance, was an avid reader and promoter of Linnaeus' treatises in Spanish America ${ }^{44}$ - by the time of the Enlightenment, naturalists and physicians from countries like Sweden or France fashioned their own peasantry, Sami "savage," or "wise woman" after the Iroquois, Barbary, or Amazonian indigenes they encountered in travelogues and early "ethnographic" observations. ${ }^{45}$ What is more, cosmopolitan naturalists like Linnaeus, Sloane, or Unánue partook of the same epistemic principles and discourses: the same Christian and humanist legacies, to be sure, but also the same empiricist dictates - the idea that all knowledge ought to be based on experience derived from the senses -, which made early modern physicians and naturalists from Habsburg Prague to viceregal Brazil open to, and even dependent upon, those simple, and "rustic" men and women who were seen to possess the most experiential and sensuous, the keenest and most immediate, apprehension of the natural world. ${ }^{46}$ Most importantly, perhaps, they also shared the same enlightened principles and discourses - a nostalgic, Ovidian ruralism and critique of civilization ${ }^{47}$ as well as the demand that science be applied, economic and vernacular, which accorded renewed significance to

43 Lisbet Koerner, "Women and Utility in Enlightenment Science," Configurations 3, no. 2 (1995): 238; 50-51; Schiebinger, "Prospecting for Drugs," 121-22.

44 Unánue's 1791 essay introduced Peruvian readers to Linnaeus's system of plant classification and binomial nomenclature. Unanue, "Botánica," 68-86.

45 For examples from Sweden, see Lisbet Koerner, Linnaeus. Nature and Nation (Cambridge MA, London: Harvard University Press, 1999), 62. For examples from France, see Brockliss and Jones, The Medical World of Early Modern France, 277. On the co-constitution of ideas about "indigeneity" in the early modern period more broadly, and on how European naturalists re-enacted practices from overseas, see Alix Cooper, Inventing the Indigenous: Local Knowledge and Natural History in Early Modern Europe (Cambridge, New York: Cambridge University Press, 2007); Cooper, "The Indigenous versus the Exotic: Debating Natural Origins in Early Modern Europe," Landscape Research 28, no. 1 (2003).

46 Scott Parrish, American Curiosity, 16. On Habsburg Prague, see Stolberg, "Learning from the Common Folks," 652. See also Andreas-Holger Maehle, Drugs on Trial: Experimental Pharmacology and Therapeutic Innovation in the Eighteenth-Century (Amsterdam:Editions Rodopi, 1999), 251-52; Martha Baldwin, "Expanding the Therapeutic Canon: Learned Medicine Listens to Folk Medicine," in Cultures of Communication from Reformation to Enlightenment, ed. James Van Horn Melton (Ashgate: Aldershot, 2002). On Mexico, see Achim, "From Rustics to Savants." On Iberian empiricism, see also Richard H. Grove, "Indigenous Knowledge and the Significance of South-West India for Portuguese and Dutch Constructions of Tropical Nature," Modern Asian Studies 30, no. 1 (1996): 130. On "tropical empiricism" in Brazil, see Ferreira Furtado, "Tropical Empiricism."

Koerner, Linnaeus: Nature and Nation, 75-77. 
unlettered "local knowers of nature" the world over. ${ }^{48}$ Enlightened engineers, physicians and antiquaries from Shropshire to Lima were persuaded there was something vital to be learned from "old women," Uzbek herders and South Asian non-Brahminic low-castes, "wild Indians," as well as enslaved men and women of African descent, about the care of animals, the meaning of antiquities, and, time and again, the uses of plants. ${ }^{49}$ Indeed, "Negro Doctors" and slave "wenches" in particular were generally believed to possess and "jealously" guard, much like "the Indians," many "marvellous" "Secrets", particularly "in the Art of Physick," which naturalists "coming from Europe" could only "obtain" through "stratagem" or "menace". 50

Global historians of science have often noted and denounced colonial naturalists' efforts to "extract knowledge from reticent informants" - recounting how "protestations of friendship, shameless flattery, monetary reward, and

48 Koerner, "Women and Utility in Enlightenment Science," 251.

49 In 1775, the physician William Withering encountered a "receipt for the cure of the dropsy," which "had long been kept a secret by an old woman in Shropshire." William Withering, An Account of the Foxglove, and Some of its Medical Uses (Birmingham: M. Swinney, 1785), 2. For a contemporary voice from Lima, encouraging the "zoologist," the "botanist," and the "physician" to seek the advice of "humble indigenes," and "mistreated slaves," see Mariano Eduardo de Rivero y Ustariz, "Prospecto," Memorial de ciencias naturales, y de industria nacional y extranjera 1, no. 1 (1827). On the Indians' privileged knowledge of antiquities, see José Hipólito Unanue, "Idea general de los monumentos del Antiguo Perú, e introducción a su estudio," El Mercurio Peruano 1 (1791): 202. Historians have argued that medicobotanical knowledge in British India also tended to privilege non-Brahminic, low-caste epistemologies. Grove, "Indigenous Knowledge and the Significance of South-West India for Portuguese and Dutch Constructions of Tropical Nature," 128-33. For Uzbek herders, see Koerner, "Women and Utility in Enlightenment Science," 251; Koerner, Linnaeus. Nature and Nation, 68.

$5^{\circ}$ Thomas Heney, MD of St David's, in the Island of Jamaica, reported in 1791 how he discovered "the secret" of the cure effected by a "negro wench" by "strategem." Thomas Heney, "On the Efficacy of the Zanthoxylon," The Medical and Physical Journal 2 (1799): 34. Also cited in Londa Schiebinger, Secret Cures of Slaves. People, Plants, and Medicine in the Eighteenth-Century Atlantic World (Stanford: Stanford University Press, 2017), 47-48. For more examples, see Schiebinger, "Prospecting for Drugs," 119. See also the various narratives in circulation about "quassia," generally thought to have been "a secret remedy" before its disclosure to Swedish naturalists, employed by "a negro named Quassi," "with uncommon success" in the Dutch plantation colony of Surinam. John Mason Good, Olinthus Gregory, and Newton Bosworth, Pantologia: A new Cyclopaedia, Comprehending a Complete Series of Essays, Treatises, and Systems, vol. $\mathrm{x}$ (London: G. Kearsley et al., 1813), QUA. On narratives about secretive "negro herbalists," see also Francisco Guerra, "Medical Almanacs of the American Colonial Period," Journal of the History of Medicine XVI, no. 3 (1961): 247-48; Richard B. Sheridan, Doctors and Slaves: A medical and Demographic History of Slavery in the British West Indies, 1680-1834 (Cambridge, New York: Cambridge University Press, 1985), 8o-81. 
eavesdropping, as well as imprisonment and torture were all tried" - but they have generally taken that reticence at face value, even accounting for it with the "suspicion" and "resentment" common to a colonial context. ${ }^{51}$ Indeed, practitioners in the field have recently suggested "recast[ing] the global history of science as a coercive form of labour management" on those grounds. ${ }^{52}$ There is certainly no denying the fact that naturalists' dealings with their informers were uneven and at times coercive; and, as during the early years of the Spanish conquest, there may well have been truth to assertions about "reticent informants" - secrecy was still a conduct it would have been prudent to adopt around 1800 . As before, however, and perhaps even more so, narrations of encounters between "rustics" and naturalists were also fraught with literary topoi, fragments of discourse that reveal "networks of production," ${ }^{53}$ threaded together by men and women from various world regions who had long engaged with and relied upon the same humanist, empiricist, and enlightened, paradigms and narratives. ${ }^{54}$ All of them consequently interpreted and made sense of the world in expected ways, imbibed from their readings, which determined their narrative choice and content. A renewed penchant for "mistrustful," "empirical" Indian knowers in natural histories of the Americas over the later 1700 s and early 1800 s was likely one result of that close epistemic connection.

\section{3}

\section{Coda}

The secretive Indian herbalist came into being in the late sixteenth century, and, like other images and ideas that travelled along the veins of colonial dominion and through time, it recurred like a wave thereafter, with ebbs of

51 Rood, "Toward a Global Labor History of Science," 265. See also Schiebinger, "Prospecting for Drugs," 123. See also Austin Alchon, "Tradiciones médicas nativas y resistencia en el Ecuador," 36.

52 Rood, "Toward a Global Labor History of Science," 266.

53 On practices of equation in the history of medicine, see Carla Nappi, "Winter Worm, Summer Grass: Cordyceps, Colonial Chinese Medicine, and the Formation of Historical Objects," in Crossing Colonial Historiographies: Histories of Colonial and Indigenous Medicines in Transnational Perspective, ed. Anne Digby, Projit B. Muhkarji, and Waltraud Ernst (Newcastle upon Tyne: Cambridge Scholars, 2010), 29-30.

54 Karen Stolley, Domesticating Empire: Enlightenment in Spanish America (Nashville: Vanderbilt University Press, 2013), 3. For the realm of naturalism, see also Juan Pimentel, "The Iberian Vision: Science and Empire in the Framework of a Universal Monarchy, 1500-1800," Osiris: A Research Journal Devoted to the History of Science and its Cultural Influences 15 (2000); Jorge Cañizares Esguerra, "Iberian Colonial Science," Isis 96 (2005). 
latency and dispersal even beyond recognition in some times and places, and flows of incidence and salience in others.

Spanish America's vibrant Creole scientific community of the late-eighteenth century, the context in which Unánue authored his essay, for instance, saw a heyday of the association between secrecy, skill in nature, and indigeneity, partly because the "mistrustful" Indian knower spoke to a creole anxiety that the Indians were the only lawful owners and heirs of American nature. Creoles like Unánue were fashioning an American identity for themselves in contrast to peninsular-born Spaniards - as the sons and daughters of the land in the late-colonial period. ${ }^{55}$ They were well aware, however, that their Americanness was called into question by the presence of those other, "original natives," the Indians - the men and women who had, as Unánue put it, inherited their knowledge about nature and history straight "from their ancestors." Indeed, the trope of the secretive Indian would gain a forceful life of its own in nineteenth-century antiquarian and archaeological writings, ${ }^{57}$ related decreasingly to the Indians' intimacy with nature and increasingly with that creole anxiety, an implicit recognition that the Indians were "the only rightful heirs of the pre-Columbian past and its archaeological remains." ${ }^{\prime 8}$ Secretive Indians were familiar and popular figures in early modern northern European - Dutch, English, or French - natural historical treatises about the virtues of Spanish American medicinal plants too, partly because the Black Legend ensured the popularity and willing acceptance of the idea that America's "natives" had guarded their knowledge out of their "revulsion" against the "barbarism of their conquerors (révoltés de la barbarie de leurs vainqueurs)." ${ }^{59}$ Colourful accounts of "mysterious" Indian "discoverers" of plant medicines also thrived with the

55 On creole identity, see David Brading, The First America: The Spanish Monarchy, Creole Patriots, and the Liberal State 1492-1867 (Cambridge, New York: Cambridge University Press, 1991). See also Bernard Lavallé, Las promesas ambiguas: Ensayos sobre el criollismo en los Andes (Lima: IRA, 1993).

56 Majluf, "The Creation of the Image of the Indian in 19th-Century Peru", 24. See also Stefanie Gänger, Relics of the Past: The Collecting and Study of Pre-Columbian Antiquities in Peru and Chile, 1837-1911, Oxford Studies in the History of Archaeology (Oxford: Oxford University Press, 2014), 136-37.

57 For narratives about how "the Indians" "guarded" the secrets of "antiquities," "inherited from their ancestors," see Mariano Eduardo de Rivero y Ustariz and Johann Jacob von Tschudi, Peruvian Antiquities, trans. Francis L. Hawks, 2nd ed. (New York: Putnam, 1857), 104-07; 29; Antonio Raimondi, "Itinerario de los viajes de Raimondi: De Lima á las montañas de Huancayo, Tarma, Pampa de Junín y Cerro de Pasco," Boletín de la Sociedad Geográfica de Lima 5, no. 4-6 (1896).

$5^{8}$ Majluf, "The Creation of the Image of the Indian in 19th-Century Peru", Chapter 8.

59 Thomas Collingwood, "Observations on the Peruvian Bark," Medical Commentaries $\mathrm{x}$ (1785): 265-66; Julien Dufau, Essai sur l'application du quinquina dans le traitement des 
increasing commercialisation and pluralism of medical and pharmacological practice in the wake of the 170os: from London to Lima, apothecaries, drug merchants, and physician-writers included stories about "wild Indians" - of whom, in their unlettered simplicity and closeness to nature mankind could reasonably expect the revelation of nature's most coveted and "excellent" remedies in advertisements, almanacs, and medical treatises. It seemingly became an effective way of popularizing and marketing remedies and standing out within a bustling "medical marketplace." ${ }^{\prime 0}$ Cosmopolitan creoles like Unánue - in the Spanish and British American colonies alike - might also have chosen to stress the Indians' secrecy and closeness to nature at a time when they were seeking to carve out a role and a space for themselves in the period's transatlantic Republic of Letters. Whereas in the European context, early modern naturalists in the wake of the seventeenth century fashioned themselves very much as discoverers of the secrets of nature that lay hidden, ${ }^{61}$ naturalists in the Americas frequently substituted that discourse for a "rhetoric of approximation" - the "arts of intimacy" - and brokerage with "the Indians." ${ }^{2}$ As various historians have argued, creole experts in the natural saw their peculiar privilege and province in mediation - not between the enlightened sciences and nature, but, much like scholastic physicians and Romance humanists with "rustics," peasants, or women, between the enlightened sciences and the inscrutable, withdrawn Indians; as intermediaries between the Indians' "empirical medicine" and "metropolitan abstraction" and ratification, ${ }^{63}$ as "go-betweens," and

fièvres intermittentes, Collection des theses soutenues a l'ecole de médicine de Paris (Paris: Didot Jeune, 1805), 10.

6o On the fetishisation of indigenous and African medical knowledge, particularly by mestizo and Creole sectors of society in Spanish America, see Steven Palmer, Doctors, Healers, and Public Power in Costa Rica, 1800-1940 (Durham, London: Duke University Press, 2003), 31. On North America, see Guerra, "Medical Almanacs of the American Colonial Period," 247-48. Irina Podgorny has found that charlatans sometimes claimed to have lived among indigenous groups who had introduced them to the secret healing powers of America's nature. Irina Podgorny, "From Lake Titicaca to Guatemala: The Travels of Joseph Charles Manó and his Wife of Unknown Name," in Nature and Antiquities: The Making of Archaeology in the Americas, ed. Philip L. Kohl, Irina Podgorny, and Stefanie Gänger (Tucson: University of Arizona Press, 2014).

61 Daniela Bleichmar, Visible Empire: Botanical Expeditions and Visual Culture in the Hispanic Enlightenment (Chicago, London: The University of Chicago Press, 2012), 48. See also Carolyn Merchant, Reinventing Eden: The Fate of Nature in Western Culture (New York, London: Routledge, 2013), xiii-xiv.

62 Achim, "From Rustics to Savants," 280. For the term and concept of the "rhetoric of approximation" see Majluf, The Creation of the Image of the Indian in 19th-Century Peru, 308.

63 Scott Parrish, American Curiosity, 217; 38. 
"filters of testimony," whose position was enhanced and rendered all the more necessary by the Indians' "permanent alterity," "epistemological distance," and inscrutability. ${ }^{64}$ Indeed, the dictates of empiricism in some measure gave colonial naturalists the means of making up for their limited access to the newest publications, prestigious institutions, or their lower rung in a - political, environmental, or economic - hierarchy. ${ }^{65}$

The trope of the skilful yet secretive Indian knower of nature did not come to an end with the colonial period. Rather, the association between indigeneity, secrecy, and skill in nature thrived in natural histories, artworks, and travelogues of the 19th and 2oth centuries. Across the Americas, secretive Indians testified, forever reluctantly, about various aspects of the territory: the topography of the land, the migrational patterns of birds, the way to gold mines and ruins, and, time and again, the healing and poisonous properties of plants. ${ }^{66}$ Indeed, the belief in a closely-kept, intuitive skill in nature peculiar to the Indians became in time a fundamental element of the repertoire of "romanticized ecological discourses" and "the received global wisdom of what constitutes Indianness," common to environmental politics and much anthropological literature on indigenous knowledge at present. ${ }^{67}$ The trope's enduring popularity was presumably both a creature and a vehicle of the hardening of an increasingly racialized dichotomy between indigenous and western knowledge that took shape in the wake of the late 170os and early 180os-an age of "Global Imperialism" and the "Great Divergence," in which northern European

64 For the argument that "creole attempts at approximation presuppose[d] the stereotype of the inscrutable Indian," see Majluf, "The Creation of the Image of the Indian in 19thCentury Peru", 356. Miruna Achim, Lagartijas medicinales: Remedios americanos y debates científicos en la Ilustración (Mexico: Conaculta/UAM-C, 2008), 75. On the settlers as mediators, in the face of native "permanent alterity" and "epistemological distance," who may have liked to stress the "Indian" herbalists' "secrets" to prove their "hard-won and rare value," see Scott Parrish, American Curiosity, 16; 216-17; 22; 29-30; 53-56. On creole scholars as trans-Atlantic "brokers," and intermediaries, see also Stefanie Gänger, "Disjunctive Circles: Modern Intellectual Culture in Cuzco and the Journeys of Incan Antiquities, c. 1877-1921," Modern Intellectual History 10, no. 2 (2013).

65 See Scott Parrish, American Curiosity, 16. On Peru, see Gänger, "Disjunctive Circles," 409.

66 See, for instance, Joshua David Bellin, "Taking the Indian Cure: Thoreau, Indian Medicine, and the Performance of American Culture," The New England Quarterly LXXIX, no. 1 (2006): 23; Scott Parrish, American Curiosity; Majluf, The Creation of the Image of the Indian in 19th-Century Peru, 351.

67 Arun Agrawal, "Dismantling the Divide between Indigenous and Scientific Knowledge," Development and Change 26 (1995): 416-17; Michael R. Dove, "Indigenous People and Environmental Politics," Annual Review of Anthropology 35 (2006): 194. 
empires first gained worldwide military, political and economic superiority. 68 For while the 19th and 2oth centuries allocated western knowledge the prerogative of universality, abstraction, impersonality, and mobility, they dealt the indigenous the reverse: 69 knowledge that was reliant on "intuition," "instinct," and evidence "directly available to the senses," for one thing, and, for another, "closed," passed down but "by word of mouth," "from generation to generation," that is, "bound" to the lives of the people who generated it. ${ }^{70}$ Indeed, secrecy presumably became an ever more deeply entrenched and predictable element of conventional wisdom about the Indians, as the natural secondary effect of attempts by outsiders to remove knowledge inherently destined to be immovable - meant, by that logic, to be stationary, bound, and unalienable. The Indians' closely kept skill in nature was likely a topos, fashioned after a plethora of Christian and humanist legacies, in the wake of the Spanish conquest. It survived, and indeed thrived, however, because it precisely fit the logic of the epistemic hierarchies and global topography of knowledge that took shape thereafter.

\section{Bibliography}

\section{Printed Sources}

Badus, Sebastianus. Anastasis corticis Peruviae; seu chinae chinae defensio, Sebastiani Badi Genvensis patrij vtriusque Nosochomij olim medici, et Publicae Sanitatis in Ciuitate Consultoris. Contrà ventilationes Joannis Jacobi Chifletii, gemitusque Vopisci Fortunati Plempii, Illustrium Medicorum. Genoa: Typis Petri Joannis Calenzani, 1663. Caldas, Francisco José de. Memoria sobre el estado de las quinas en generaly en particular sobra la de Loja, Anales de la Universidad Central de Quito. Quito: Tipografía y Encuadernación Saletiana, 1907 (1809).

Citte, François. "De l'usage du quinquina et des règles de son application dans les fièvres intermittentes." In Collection des thèses soutenues a l'école de médicine de Montpellier pendant l'an XII, edited by L'École de Médicine de Montpellier, 3-23. Montpellier: G. Izar et A. Richard, 1804.

68 On "The First Age of Global Imperialism," Christopher A. Bayly, "The First Age of Global Imperialism, c. 1760-1830," The Journal of Imperial and Commonwealth History XXVI, no. 2 (1998). On the "Great Divergence," see Kenneth Pomeranz, The Great Divergence: China, Europe, and the Making of the Modern World (Princeton: Princeton University Press, 2000).

69 Marwa Elshakry, "When Science Became Western: Historiographical Reflections," Isis 101. Focus. Global Histories of Science (2010). Agrawal, "Dismantling the Divide between Indigenous and Scientific Knowledge," 416-17. 
Collingwood, Thomas. "Observations on the Peruvian Bark." Medical Commentaries $\mathrm{x}$ $(1785): 265^{-75}$.

Condamine, Charles-Marie de la. "Sur l'arbre du quinquina." Mémoires de l'Academie Royale MDCCXL (1738 (1737)): 226-44.

Crest de Saint-Aubin, Stéphanie Félicité du, Countess de Genlis. Zuma, ou la découverte du quinquina. Paris: Maradan, Libraire, 1818.

D.F.D.P.D.L.M.L. "Carta remitida a la Sociedad, que publica con algunas notas." Mercurio Peruano, no. 344 (1794): 255-62.

Dufau, Julien. Essai sur l'application du quinquina dans le traitement des fièvres intermittentes, Collection des theses soutenues a l'ecole de médicine de Paris. Paris: Didot Jeune, 1805 .

Fernández de Oviedo y Valdés, Gonzalo. Primera parte de la historia natural y general de las indias, yslas e tierra firme del mar oceano; escripta por el capitan Gonçalo Hernández de Oviedoy Valdés, alcayde de la fortaleza de la ciudad de Sancto Domingo de laysla Española, y cronista de la sacra, cesárea y catholicas majestades del emperador don Carlos quinto de tal nombre, rey de España, e de la sereníssima e muy poderosa reyna doña Juana su madre nuestros señores. Por cuyo mandado el auctor escrivió las cosas maravillosas que hay en diversas yslas e partes destas indias e imperio de la corona real de castilla, según lo vido e supo en veynte e dos años e más que ha que vive e reside en aquellas partes. La qual historia comiença en el primero descubrimiento destas indias, y se contiene en veynte libros este primero volumen. Sevilla: Iuam Cromberger, 1535 .

Garcia de la Vega, José Vicente. Discurso critico que sobre el uso de las lagartijas, como especifico contra muchas enfermedades, produjo D. Joseph Vicente García de la Vega, Profesor de Medicina en la Imperial Corte de Mexico. Mexico: Imprenta de D. Felipe de Zúñiga y Ontiveros, 1782.

Guevara, José. Historia de la conquista del Paraguay, Rio de la Plata y Tucuman. Buenos Aires: E. Ostwald, 1882 (around 1766).

Heney, Thomas. "On the Efficacy of the Zanthoxylon." The Medical and Physical Journal 2 (1799): 31-34.

Humboldt, Alexander von. Reise in die Äquinoktial-Gegenden des Neuen Kontinents, 2 vols., vol. 2. Frankfurt, Leipzig: Insel-Verlag, 1991 (1814).

Mason Good, John, Olinthus Gregory, and Newton Bosworth. Pantologia. A new Cyclopaedia, Comprehending a Complete Series of Essays, Treatises, and Systems, Alphabetically Arranged; with a General Dictionary of Arts, Sciences, and Words: the Whole Presenting a Distinct Survey of Human Genius, Learning, and Industry, vol. x. London: G. Kearsley et al., 1813 .

Monardes, Nicolás. Joyfull Newes out of the Newe Founde Worlde. London: Willyam Norton, 1577 . 
Monardes, Nicolás. Primera y segunda y tercera partes de la historia medicinal, de las cosas que se traen de nuestras Indias Occidentales, que siruen en Medicina. Sevilla: Alonso Escriuano, 1574.

Motherby, George. A New Medical Dictionary; Or General Repository of Physic Containing an Explanation of the Terms, and a Description of the Various Particulars Relating to Anatomy, Physiology, Physic, Surgery, Materia Medica, Pharmacy \&c. \&c. \&c. London: J. Johnson, 1775.

Quack, Jan de. Zuma, of De ontdekking van den kina-bast: tooneelspel in vier bedrijven. Amsterdam: J. C. van Kesteren, 1819.

Raimondi, Antonio. "Itinerario de los viajes de Raimondi. De Lima á las montañas de Huancayo, Tarma, Pampa de Junín y Cerro de Pasco." Boletín de la Sociedad Geográfica de Lima 5, no. 4-6 (1896): 122-74.

Rivero y Ustariz, Mariano Eduardo de. "Prospecto." Memorial de ciencias naturales, y de industria nacional y extranjera; redactado por M. de Rivero y de N. de Piérola 1, no. 1 (1827): $1-3$.

Rivero y Ustariz, Mariano Eduardo de, and Johann Jacob von Tschudi. Peruvian Antiquities, translated by Francis L. Hawks, 2 ed. New York: Putnam, 1857.

Sloane, Hans. A voyage to the islands Madera, Barbados, Nieves, S. Christophers and Jamaica, with the Natural History of the Herbs and Trees, Four-footed Beasts, Fishes, Birds, Insects, Reptiles, \&c. of the last of those islands; to which is prefix'd, an Introduction, Wherein is an Account of the Inhabitants, Air, Waters, Diseases, Trade, \&c. of that Place, with some Relations concerning the Neighbouring Continent, and Islands of America, 2 vols., vol. 1. London: B.M., 1707.

Tschudi, Johann Jakob von. Peru: Reiseskizzen aus den Jahren 1838-1842, 2 vols., vol. 2. St. Gallen: Scheitlin und Zollikofer, 1846.

Unanue, José Hipólito. “Idea general de los monumentos del Antiguo Perú, e introducción a su estudio." El Mercurio Peruano 1 (1791/o3/17 1791): 201-o8.

Unanue, José Hipólito. "Botánica: Introducción a la descripción científica de las plantas del Perú, vol. II, núms. 43 y 44 (29 de mayo y 2 de junio de 1791), 68-86.” In El Mercurio Peruano: 179o-1795. Antología, edited by Jean-Pierre Clément, 93-114. Frankfurt am Main: Vervuert, 1998 (1791).

Withering, William. An Account of the Foxglove, and Some of its Medical Uses: with Practical Remarks on Dropsy, and Other Diseases. Birmingham: M. Swinney, 1785.

\section{Literature}

Achim, Miruna. "From Rustics to Savants: Indigenous Materia medica in EighteenthCentury Mexico." Studies in History and Philosophy of Biological and Biomedical Sciences 42 (2011): 275-84.

Achim, Miruna. Lagartijas medicinales: Remedios americanos y debates científicos en la Ilustración. Mexico: Cohjnaculta/UAM-C, 2008. 
Achim, Miruna. "Los remedios de los indios 'nuevamente descubiertos'. In Lagartijas medicinales: Remedios americanos y debates científicos en la Ilustración, edited by Miruna Achim, 73-119. Mexico: Conaculta/UAM-C, 2008.

Agrawal, Arun. "Dismantling the Divide between Indigenous and Scientific Knowledge." Development and Change 26 (1995): 413-39.

Arens, William. The Man-Eating Myth: Anthropology and Anthropophagy. Oxford, New York: Oxford University Press, 1979.

Austin Alchon, Suzanne. "Tradiciones médicas nativas y resistencia en el Ecuador." In Saberes andinos: Ciencia y tecnología en Bolivia, Ecuador y Perú, edited by Marcos Cueto, 15-36. Lima: IEP, 1995.

Baldwin, Martha. "Expanding the Therapeutic Canon: Learned Medicine Listens to Folk Medicine." In Cultures of Communication from Reformation to Enlightenment, edited by James Van Horn Melton, 239-56. Ashgate: Aldershot, 2002.

Bayly, Christopher A. "The First Age of Global Imperialism, c. 1760-183o." The Journal of Imperial and Commonwealth History XXVI, no. 2 (1998): 28-47.

Bellin, Joshua David. "Taking the Indian Cure: Thoreau, Indian Medicine, and the Performance of American Culture." The New England Quarterly LXXIX, no. 1 (2006): $3-36$.

Bleichmar, Daniela. "Books, Bodies, and Fields: Sixteenth-Century Transatlantic Encounters with New World Materia Medica." In Colonial Botany: Science, Commerce, and Politics in the Early Modern World, edited by Londa Schiebinger and Claudia Swan, 83-99. Philadelphia: University of Pennsylvania Press, 2005.

Bleichmar, Daniela. Visible Empire: Botanical Expeditions and Visual Culture in the Hispanic Enlightenment. Chicago, London: The University of Chicago Press, 2012.

Brading, David. The First America: The Spanish Monarchy, Creole Patriots, and the Liberal State 1492-1867. Cambridge, New York: Cambridge University Press, 1991.

Brockliss, Laurence and Colin Jones. The Medical World of Early Modern France. Oxford: Clarendon Press, 1997.

Cahill, David. "Colour by Numbers: Racial and Ethnic Categories in the Viceroyalty of Peru, 1532-1824." Journal of Latin American Studies 26, no. 2 (1994): 325-46.

Cañizares Esguerra, Jorge. "Iberian Colonial Science." Isis 96 (2005): 64-70.

Cook, Harold J. Matters of Exchange: Commerce, Medicine and Science in the Age of Empire. Hyderabad: Orient Longman, 2008.

Cooper, Alix. "The Indigenous versus the Exotic: debating natural origins in early modern Europe." Landscape Research 28, no. 1 (2003): 51-6o.

Cooper, Alix. Inventing the Indigenous: Local Knowledge and Natural History in Early Modern Europe. Cambridge, New York: Cambridge University Press, 2007.

De Vos, Paula. "The Rare, the Singular, and the Extraordinary: Natural History and the Collection of Curiosities in the Spanish Empire." In Science in the Spanish and 
Portuguese Empires, 1500-1800, edited by Daniela Bleichmar, Paula de Vos, Kristin Huffine, and Kevin Sheehan, 271-89. Stanford: Stanford University Press, 2009.

Dove, Michael R. "Indigenous People and Environmental Politics." Annual Review of Anthropology 35 (2006): 191-208.

Elshakry, Marwa. "When Science Became Western: Historiographical Reflections." Isis 101. Focus. Global Histories of Science (2010): 98-109.

Ferreira Furtado, Júnia, ed. Luís Gomes Ferreira, Erário mineral. Rio de Janeiro: Editora FIOCRUZ, 2002 (1735).

Ferreira Furtado, Júnia. “Tropical Empiricism: Making Medical Knowledge in Colonial Brazil." In Science and Empire in the Atlantic World, edited by James Delbourgo and Nicholas Dew, 127-51. New York. London: Routledge, 2008.

Gänger, Stefanie. "Disjunctive Circles: Modern Intellectual Culture in Cuzco and the Journeys of Incan Antiquities, c. 1877-1921." Modern Intellectual History 10, no. 2 (2013): 399-414.

Gänger, Stefanie. Relics of the Past: The Collecting and Study of Pre-Columbian Antiquities in Peru and Chile, 1837-1911, Oxford Studies in the History of Archaeology. Oxford: Oxford University Press, 2014.

Grafton, Anthony. New Worlds, Ancient Texts: The Power of Tradition and the Shock of Discovery. Cambridge MA, London: Harvard University Press, 1992.

Greene, Roland. "Petrarchism among the Discourses of Imperialism." In America in European Consciousness, 1493-1750, edited by Karen Ordahl Kupperman, 130-65. Chapel Hill, London: University of North Carolina Press, 1995.

Grove, Richard H. "Indigenous Knowledge and the Significance of South-West India for Portuguese and Dutch Constructions of Tropical Nature." Modern Asian Studies 30, no. 1 (1996): 121-43.

Guerra, Francisco. "Medical Almanacs of the American Colonial Period." Journal of the History of Medicine XVI, no. 3 (1961):234-55.

Heller, Dana. "Holy Fools, Secular Saints, and Illiterate Saviors in American Literature and Popular Culture." CLCWeb: Comparative Literature and Culture 5, no. 3 (2003): $1-15$.

Klauth, Carlo. Geschichtskonstruktion bei der Eroberung Mexikos: Am Beispiel der Chronisten Bernal Diáz del Castillo, Bartolomé de las Casas und Gonzalo Fernández de Oviedo. Hildesheim, Zurich, New York: Georg Olms Verlag, 2012.

Koerner, Lisbet. Linnaeus: Nature and Nation. Cambridge MA, London: Harvard University Press, 1999.

Koerner, Lisbet. "Women and Utility in Enlightenment Science." Configurations 3, no. 2 (1995): 233-55.

Krech, Shepard. The Ecological Indian: Myth and History. New York: W. W. Norton, 1999. Lavallé, Bernard. Las promesas ambiguas: Ensayos sobre el criollismo en los Andes. Lima: IRA, 1993. 
Lowood, Henry. "The New World and the European Catalog of Nature." In America in European Consciousness, 1493-1750, edited Karen Ordahl Kupperman, 295-323. Chapel Hill, London: University of North Carolina Press, 1995.

Maehle, Andreas-Holger. Drugs on Trial: Experimental Pharmacology and Therapeutic Innovation in the Eighteenth-Century, Clio Medica/The Wellcome Institute Series in the History of Medicine. Amsterdam: Editions Rodopi, 1999.

Majluf, Natalia. "The Creation of the Image of the Indian in 19th-Century Peru: The Paintings of Francisco Laso (1823-1869)." PhD diss., University of Texas, 1996).

McClure, Julia. The Franciscan Invention of the New World. Basingstoke: Palgrave, 2016. Merchant, Carolyn. Reinventing Eden: The Fate of Nature in Western Culture. New York, London: Routledge, 2013 .

Mignolo, Walter D., Margaret R. Greer, and Maureen Quilligan. "Introduction." In Rereading the Black Legend: Discourses of Religious and Racial Difference in the Renaissance Empires, edited by Walter D. Mignolo, Margaret R. Greer, and Maureen Quilligan, 1-27. Chicago, London: The University of Chicago Press, 2007.

Murphy, Kathleen S. "Translating the Vernacular: Indigenous and African Knowledge in the Eighteenth-Century British Atlantic." Atlantic Studies 8, no. 1 (2011): 29-48.

Nappi, Carla. "Winter Worm, Summer Grass: Cordyceps, Colonial Chinese Medicine, and the Formation of Historical Objects." In Crossing Colonial Historiographies: Histories of Colonial and Indigenous Medicines in Transnational Perspective, edited by Anne Digby, Projit B. Muhkarji, and Waltraud Ernst, 21-35. Newcastle upon Tyne: Cambridge Scholars, 2010.

Norton, Marcy. Sacred Gifts, Profane Pleasures: A History of Tobacco and Chocolate in the Atlantic World. Ithaca, London: Cornell University Press, 2008.

O'Phelan Godoy, Scarlett. Kurakas sin sucesiones: Del cacique al alcalde de indios. Perúy Bolivia 1750-1835. Cuzco: СвС, 1997.

Ordahl Kupperman, Karen. "Introduction: The Changing Definition of America." In America in European Consciousness, 1493-1750, edited by Karen Ordahl Kupperman, 1-32. Chapel Hill, London: University of North Carolina Press, 1995.

Pagden, Anthony. The Fall of Natural Man: The American Indian and the Origins of Comparative Ethnology. Cambridge, New York: Cambridge University Press, 1982.

Palmer, Steven. Doctors, Healers, and Public Power in Costa Rica, 1800-1940. Durham, London: Duke University Press, 2003.

Park, Katherine. Secrets of Women: Gender, Generation, and the Origins of Human Dissection. New York: Zone Books, 2006.

Pimentel, Juan. "The Iberian Vision: Science and Empire in the Framework of a Universal Monarchy, 1500-180o." Osiris: A Research Journal Devoted to the History of Science and its Cultural Influences 15 (2000): 17-30.

Podgorny, Irina. "From Lake Titicaca to Guatemala: The Travels of Joseph Charles Manó and his Wife of Unknown Name." In Nature and Antiquities: The Making of 
Archaeology in the Americas, edited Philip L. Kohl, Irina Podgorny, and Stefanie Gänger, 125-44. Tucson: University of Arizona Press, 2014.

Pomeranz, Kenneth. The Great Divergence: China, Europe, and the Making of the Modern World. Princeton: Princeton University Press, 2000.

Rood, Daniel. "Toward a Global Labor History of Science." In Global Scientific Practice in an Age of Revolutions, 1750-1850, edited by Patrick Manning and Daniel Rood, 255-74. Pittsburgh: University of Pittsburgh Press, 2016.

Ross Griffel, Margaret. "ZUMA, or, the Tree of Health." In Operas in English: A Dictionary, edited by Margaret Ross Griffel, 556. Plymouth: Scarecrow Press, 2013.

Rousseau, George S. and Roy Porter. "Introduction: Approaching Enlightenment Exoticism." In Exoticism in the Enlightenment, edited by George S. Rousseau and Roy Porter, 1-22. Manchester, New York: Manchester University Press, 1990.

Rowe, John Howland, ed. Inca Religion and Customs by Father Bernabe Cobo. Austin: University of Texas Press, 1990 (1653).

Sanchez-Albornoz, Nicolas. "El trabajo indigena en los Andes: teorías del siglo XVI." Revista ecuatoriana de historia económica 2 (1987): 153-81.

Schiebinger, Londa. Plants and Empire. Cambridge MA, London: Harvard University Press, 2004.

Schiebinger, Londa. "Prospecting for Drugs: European Naturalists in the West Indies." In The Postcolonial Science and Technology Studies Reader, edited by Sandra Harding, 110-26. Durham, London: Duke University Press, 2011.

Schiebinger, Londa. Secret Cures of Slaves: People, Plants, and Medicine in the EighteenthCentury Atlantic World. Stanford: Stanford University Press, 2017.

Scott Parrish, Susan. American Curiosity: Cultures of Natural History in the Colonial British Atlantic World. Chapel Hill: University of North Carolina Press, 2006.

Shapin, Steven. A Social History of Truth: Civility and Science in Seventeenth-Century England. Chicago, London: The University of Chicago Press, 1994.

Sheridan, Richard B. Doctors and Slaves: A medical and Demographic History of Slavery in the British West Indies, 1680-1834. Cambridge, New York: Cambridge University Press, 1985 .

Stolberg, Michael. "Learning from the Common Folks: Academic Physicians and Medical Lay Culture in the Sixteenth Century." Social History of Medicine 27, no. 4 (2014): 649-67.

Stolley, Karen. Domesticating Empire: Enlightenment in Spanish America. Nashville: Vanderbilt University Press, 2013. 